\title{
EVALUASI KEBIJAKAN SOSIAL DALAM PENINGKATAN TARAF HIDUP MASYARAKAT RENTAN MISKIN DI JAWA TIMUR
}

\author{
Hari Fitrianto $^{1}$, Fahrul Muzaqqi ${ }^{2}$, Ali Sahab ${ }^{3}$ \\ ${ }^{1}$ Departemen Ilmu Sosial dan Ilmu Politik, Fakultas Ilmu Soisal dan Ilmu Politik, Universitas \\ Airlangga \\ hari.fitrianto@fisip.unair.ac.id \\ ${ }^{2}$ Departemen Ilmu Sosial dan Ilmu Politik, Fakultas Ilmu Soisal dan Ilmu Politik, Universitas \\ Airlangga \\ ${ }^{3}$ Departemen Ilmu Sosial dan Ilmu Politik, Fakultas Ilmu Soisal dan Ilmu Politik, Universitas \\ Airlangga
}

\begin{abstract}
The Jalin Matra Program (Another Path to a Prosperous Society) of The East Java Government under the leadership of Soekarwo-Saifullah Yusuffor the 2014-2019 period was quite effective in reducing poverty levels. This study aims to measure the effectiveness of the program, obstacles in the field, the impact of policy implementation, especially for poor vulnerable families. This study uses a mixed method. Quantitatively, it took 100 respondents from the beneficiary villages spread over four sample districts (Sumenep, Jember, Malang, and Madiun) and deepened them with qualitative method to get an in-depth picture (thick description). The results of this study are: (1) $54 \%$ of respondents stated that the poverty alleviation program was running well; (2) the biggest obstacle faced in program implementation is the classification of target households; (3) the impact of the implementation of the poverty alleviation program is that $63 \%$ of respondents stated that their income had increased.
\end{abstract}

Keywords: Policy evaluation, social policy, poverty elevation program

\section{PENDAHULUAN}

Pemerintah provinsi Jawa Timur terus berupaya melakukan pengentasan kemiskinan, salah satu upaya tersebut adalah dengan melaksanakan program Jalan lain Menuju Masyarakat Sejahtera atau umum disingkat menjadi Jalin Matra. Program Jalan Lain menuju Masyarakat Sejahtera bisa kita artikan sebagai keseriusan upaya dari Gubernur terpilih Dr. Soekarwo dalam mewujudkan visi misinya pada saat kampanye, yakni "Makmur bersama wong cilik melalui APBD untuk rakyat". Program Jalan Lain menuju Masyarakat Sejahtera sendiri adalah program pengganti Jalan Lain Menuju Kesejahteraan (Jalin Kesra) yang sudah berlangsung selama lima tahun, mulai 2009 sampai 2014, tepatnya pada periode pertama kepemimpinan Gubernur Soekarwo dan Wakil Gubernur Saifulah Yusuf atau yang lebih dikenal dalam tagline kampanyenya sebagai Karsa Jilid I.

Bisa jadi kemenangan Karsa Jilid I maupun Jilid II dikarenakan kepercayaan publik Jawa Timur kepada visi misi kandidat tersebut untuk memberikan jawaban maupun solusi atas permasalahan yang membelit publik Jawa Timur, yakni masalah kemiskinan. Itikad baik pemerintah provinsi tidak hanya menjadi jargon pada saat kampanye, namun telah berhasil dimanifestasikan dalam penurunan angka kemiskinan di Jawa Timur, seperti halnya data yang dilansir oleh Badan Pusat Statistik Nasional (BPS). Data BPS, menunjukkan bahwa tingkat kemiskinan di Indonesia pada bulan September 2014 sebesar 27,73 juta orang atau 10,96 \%. Sedangkan data Badan Pusat Statistik (BPS) Provinsi Jawa Timur, bahwa hasil Survei Sosial Ekonomi Nasional (Susenas), penduduk miskin Jawa Timur sejak Maret 2009 sampai 
dengan September 2014 mengalami penurunan, meskipun ada pelambatan penurunan angka kemiskinan. Pada Maret 2009 jumlah penduduk miskin di Jawa Timur sebesar 6.022 .590 jiwa $(16,68 \%)$ dan pada September 2014 sebesar 4.748 .420 jiwa (12,28\%). Artinya selama 5 tahun telah terjadi penurunan sejumlah 1.274.170 jiwa (4,4\%) (BPS, 2015). Penurunan angka kemiskinan ini menunjukkan bahwa program-program penanggulangan kemiskinan yang telah dilaksanakan oleh Pemerintah Provinsi Jawa Timur cukup efektif dalam memberikan kontribusi penurunan angka kemiskinan (www.bapemas.jatimprov.go.id).

Bermaksud untuk meneruskan keberhasilan pada kepemimpinan Karsa Jilid I dalam usahanya memerangi kemiskinan, Karsa Jilid II me-launching program anti kemiskinan yang baru yakni Jalan Lain menuju Masyarakat Sejahtera. Berbeda dari program terdahulu yaitu Jalin Kesra, Jalin Matra mencoba untuk memotret kemiskinan tidak dalam dimensi yang tunggal. Hal tersebut terlihat pada varian dari program Jalin Matra yang terdiri dari tiga program yaitu; penanggulangan Feminisasi Kemiskinan (PFK), Bantuan Rumah Tangga Sangat Miskin (RTSM), Penanggulangan Kerentanan Kemiskinan (PK2).

Salah satu data kemiskinan yang digunakan Pemerintah Provinsi Jatim untuk memotret ragam dimensi kemiskinan di Jawa Timur adalah berdasarkan data Program Perlindungan Sosial Tahun 2011 (PPLS 11) yang bersumber dari Basis Data Terpadu Tim Nasional Percepatan Penanggulangan Kemiskinan (TNP2K). Data kemiskinan tersebut diperoleh melalui sensus berdasarkan nama dan alamat (by name by adress) rumah tangga dengan status kesejahteraan terendah. Dari sensus tersebut menunjukkan hasil data kemiskinan yang dikategorikan dalam tiga tingkatan (desil), yakni: Desil 1 (Rumah Tangga dengan status kesejahteraan 10\% terendah) sebesar 1.230.042 Rumah Tangga atau 5.174.675 jiwa; Desil 2 (Rumah Tangga dengan status kesejahteraan 11\%-20\% terendah) sebesar 1.189.670 Rumah Tangga atau 3.932.347 jiwa; Desil 3 (Rumah Tangga dengan status kesejahteraan 21\%-30\% terendah) sebesar 1.189.652 Rumah Tangga atau 3.527.666 jiwa.

Program Jalin Matra Bantuan Rumah Tangga Sangat Miskin (RTSM) dilaksanakan dengan sasaran kepada tangga sangat miskin yang masuk pada Desil 1 dengan status kesejahteraan 5\% terendah berdasarkan data PPLS 2011. Rumah tangga yang masuk ke dalam Desil 1 dapat diklasifikasikan sebagai rumah tangga miskin dan sangat miskin. Kelompok rumah tangga strata sangat miskin ini relatif belum pernah menjadi target spesifik prioritas berbagai penanggulangan kemiskinan secara eksklusif. Program penanggulangan kemiskinan selama ini mengalami kendala membidik strata sangat miskin secara spesifik dan tepat sasaran, karena ketiadaan basis data mengenai keberadaan mereka (by name by address). Akibatnya, kemiskinan sering diperlakukan secara homogen, padahal kebutuhan rumah tangga strata sangat miskin untuk keluar dari kemiskinan relatif berbeda dengan strata miskin, apalagi strata hampir miskin.

Program Jalin Matra PK2 masih merupakan Pilot Project, yang secara khusus membidik kelompok rumah tangga yang berada pada desil 2 dan desil 3 atau mereka yang berada dalam kategori kelompok Rumah Tangga yang Hampir Miskin (RTHM). Kelompok masyarakat pada desil 2 dan 3 
adalah kelompok masyarakat yang rentan, meskipun dalam kesehariannya kelompok masyarakat ini tidak bisa dikategorikan dalam kelompok masyarakat miskin. Akan tetapi kelompok masyarakat ini akan sangat rentan untuk masuk dalam kelompok masyarakat miskin (desil 1) jika terjadi force majour jatuh sakit, kehilangan tulang punggung keluarga, bencana alam, dsb. Dalam kelakar yang terbatas, kelompok dalam desil 2 dan 3 sering disebut sebagai kelompok "sadikin" sakit sedikit jatuh miskin. Melalui Pilot Project Jalin Matra PK2, Pemerintah Provinsi Jawa Timur berniat untuk menolong kelompok masyarakat rentan yang berada pada Desil 2 dan 3 agar tidak terperosok ke dalam jurang kemiskinan, atau kelompok desil satu.

Upaya melihat kemiskinan bukan sebagai dimensi yang tunggal, juga dicerminkan pada perumusan program Penanggulangan Feminisasi Kemiskinan (PFK). Program tersebut secara spesifik ditujukan untuk menangani kemiskinan perempuan, terutama bagi rumah tangga yang Kepala Rumah Tangga Perempuan (KRTP). Program Penanggulangan Feminisasi Kemiskinan, tidak hanya sebagai upaya jangka pendek untuk memberikan bantuan kepada KRTP tetapi terlebih daripada itu adalah sebagai program yang berkelanjutan dalam rangka untuk mengantisipasi adanya perangkap kemiskinan (poverty trap) pada KRTP. Permasalahan kemiskinan secara keseluruhan menjadi perhatian Pemerintah Provinsi Jawa Timur, namun secara khusus saat ini mencermati adanya peningkatan populasi perempuan yang hidup di bawah garis kemiskinan serta semakin tumbuh dan akutnya kondisi kemiskinan yang terjadi pada rumah tangga dengan kepala rumah tangga perempuan. Fenomena yang sering dikenal sebagai feminisasi kemiskinan atau kemiskinan yang semakin berwajah perempuan tersebut memerlukan upaya khusus dalam rangka penanganannya.

Sebagai sebuah kebijakan baru (baca: pilot project) tentu Jalin Matra tidak lepas dari sedikit kesalahan. Maka penting untuk tetap mengawal kebijakan tersebut agar tetap pada jalur ideal yang telah diancangkan (on the track), atau paling tidak menjaga agar deviasi antara normatif program dan praktik program tidak berjarak terlalu lebar, maka penting untuk melakukan evaluasi kebijakan yang sedang di implementasikan. Sehingga fungsi evaluasi kebijakan tidak sekedar memberikan rapor akhir yang berisi penghakiman, melainkan lebih pada fungsi pengawalan sehingga kebijakan bisa selalu mengkoreksi dirinya pada saat bersamaan ketika kebijakan tersebut sedang diimplementasikan.

Penelitian ini berfokus pada empat pertanyaan berikut. Pertama, bagaimana hasil evaluasi program Penanggulangan Kerentanan kemiskinan (PK2) di lokasi penelitian? Kedua, apa saja kendala yang dapat menjadi hambatan dalam implementasi program Penanggulangan kerentanan kemiskinan (PK2) di lokasi penelitian? Ketiga, bagaimana dampak implementasi program Penanggulangan kerentanan kemiskinan (PK2) terhadap peningkatan pendapatan Keluarga Rentan miskin di lokasi penelitian? Keempat, apa alternatif strategi/model untuk mengoptimalkan program penanggulangan kerentanan kemiskinan (PK2) terhadap peningkatan pendapatan keluarga rentan miskin di lokasi penelitian? 
Akan lebih bagus kalua penulis menggunakan perspektif teoritis tertentu di dalam melakukan evaluasi dan analisis. Perspektif teoritis itu pula yan bisa dijadikan kerangka analisis di dalam melalukan abalisis atau penilaian data yang ada di Lapangan.

\section{KEBIJAKAN SOSIAL}

Kebijakan sosial adalah bagian dari kebijakan publik yang fokus pada upaya pemenuhan kesejahteraan sosial. Jadi secara etimologi makna terma "kebijakan" pada kebijakan-sosial adalah kebijakan publik, sedangkan terma "sosial" berkelindan dengan isu kesejahteraan. Singkatnya kebijakan sosial menunjuk pada upaya yang dilakukan oleh pemerintah untuk mewujudkan kesejahteraan bagi warganya, terlebih bagi mereka yang memiliki pendapatan rendah dan berada di bawah garis kemiskinan. (Suharto, 2005)

Kebijakan sosial memiliki fungsi, pertama, fungsi preventif yang bertugas untuk melakukan pencegahan masalah sosial. Kedua, fungsi kuratif yang berguna untuk mengatasi masalah sosial yang sudah terjadi. Ketiga, fungsi development yang berkaitan dengan kewajiban negara untuk mensejahterakan dan memberdayakan masyarakatnya (Edu Suharto, 2006). Sepertihalnya kebijakan publik lainnya, kebijakan social juga tunduk pada kaidah universal kebijakan publik, diantaranya; berorientasi pada maksud dan tujuan yang terencana, Tindakan yang terarah dan terpola, kebijakan adalah apa yang dilakukan bukan apa yang diinginkan.

Seperti yang dikemukakan oleh William Dunn (2000), kebijakan publik memiliki beberapa tahapan yakni, pertama penyusunan agenda kebijakan. Pada tahap ini ditentukan permasalahan publik yang perlu dipecahkan. Masalah publik berbeda dengan masalah privat, masalah publik dipahami sebagai belum terpenuhinya aspirasi dari publik terkait kebutuhan dasar, nilai, atau akses pada pelayanan, dimana pemenuhannya hanya dimungkinkan melalui intervensi negara.

Kedua, formulasi kebijakan pada tahapan ini masalah yang telah ditentukan sebagai agenda kebijakan kemudian dianalisis dan dirumuskan beberapa pilihan kebijakan yang bisa memecahkan masalah tersebut. Ketiga, adopsi kebijakan dan implementasi kebijakan ditandai dengan telah ditentukan alternatif atau opsi rencana kebijakan yang terbaik. Kemudian kebijakan ini didukung dengan anggaran dan juga aparat birokrasi. Keempat, evaluasi kebijakan, pada tahap ini kebijakan yang diimplementasikan dinilai dampak dan tingkat keberhasilannya.

August Osterle (2002) mengembangkan kerangka analisis evaluasi kebijakan sosial yang menggunakan tiga dimensi kunci analisis yang terdiri dari dimensi sumberdaya, penerima manfaat kebijakan, dan prinsip pelayanannya. Dalam artikel ini, tiga dimensi analisis kebijakan sosial ini akan digunakan sebagai pisau analisis utama untuk melakukan evaluasi kebijakan Jalin Matra. 


\section{METODE PENELITIAN}

Penelitian ini menggunakan metode kombinasi kuantitatif dan kualitatif. Penelitian kualitatif dianggap tepat digunakan dengan alasan untuk mendapatkan gambaran secara mendalam (thick description) atas subjek yang diteliti. Dalam hal ini perihal bagaimana gambaran kebijakan Jalin Matra selama ini di Provinsi Jawa Timur. Sedangkan penelitian kuantitatif dilakukan untuk mendapatkan analisa hubungan antar variabel yang ditentukan oleh tim peneliti kaitannya dengan bagaimana kebijakan Jalin Matra saat diimplementasikan.

Lokasi kegiatan adalah Kabupaten Malang, Kabupaten Madiun, kabupaten Jember, dan Kabupaten Sumenep. Kabupaten Malang meliputi: desa Sindurejo, Kecamatan Gedangan, desa Pandansari, kecamatan Ngantang, Desa Sumbertangkil, Kecamatan Tirtoyudo, dan Desa Pandansari, Kecamatan Poncokusumo. Kabupaten Madiun meliputi: Desa Kuwu, Decamatan Balerejo, Desa Sareng, Kecamatan Geger. Kabupaten Jember meliputi: Desa Lembengan, Kecamatan Ledokombo, Desa Mumbulsari, Kecamatan Mumbulsari, Desa Patempuran, Kecamatan Kalisat, Desa Pondokrejo, Kecamatan Tempurejo. Sementara Kabupaten Sumenep meliputi: Desa Pankondang, Kecamatan Rubaru, Desa Nyapar, Kecamatan Dasuk, Desa Larangan Kerta, Kecamatan Batu Putih, Desa Juluk, Kecamatan Saronggi.

Metode pengumpulan data dalam penelitian ini dikategorikan ke dalam dua metode. Pertama, pengumpulan data untuk kualitatif deskriptif dilakukan melalui tiga tahapan yaitu: wawancara mendalam, observasi dan dokumentasi. Pelaksanaan pengumpulan data di lapangan diatur melalui strategi sebagai berikut: (a) penentuan informan secara purposive sampling (untuk informan kunci) dan snowball untuk pengembangan informan, (b) mewawancarai informan, (c) membuat catatan, (d) mengajukan pertanyaan deskriptif dan struktural, 5) melakukan analisis wawancara, (e) membuat analisis domain, (f) menemukan tema-tema berkaitan dengan implementasi Jalin Matra, dan (g) menuliskan laporan penelitian. Kedua, pengumpulan data kuantitatif eksplanatif dilakukan dengan menggunakan instrumen kuesioner dengan responden 100, responden adalah warga desa yang tercatat sebagai penerima program PK2 di empat Kabupaten sampel, untuk mendapatkan hubungan sejumlah variabel tentang kebijakan Jalin Matra yang berlangsung ditahun 2015. Pengumpulan data kuantitatif ini menggunakan Metode Sampling atau Kuota Sampling. Pengambilan sampel secara kuota atau jumlah tertentu karena dianggap bisa merefleksikan populasi. Pemilihan kuota sampling dimaksudkan untuk menguji hipotesis yang telah dibuat dengan melihat hubungan antara variabel yang diuji.

Pemeriksaan keabsahan data pada penelitian ini menggunakan teknik triangulasi sumber data, dilakukan dengan: (a) membandingkan data hasil pengamatan dan hasil wawancara, (b) membandingkan apa yang dikatakan orang di depan umum dengan apa yang dikatakan secara pribadi, (c) membandingkan keadaan dalam perspektif seseorang dengan pendapat dan pandangan orang lain, (d) membandingkan hasil wawancara dengan isi dokumen. 


\section{HASIL PENELITIAN}

Seperti telah disinggung pada sub bab sebelumnya, evaluasi kebijakan Jalin Matra akan didasarkan pada tiga dimensi kunci analisis milik August Osterle. Yakni dimensi Penerima manfaat, dimensi sumberdaya, dan dimensi prinsip pelayanan. Pada dimensi penerima manfaat, kami melakukan identifikasi siapakah yang menjadi target kebijakan Jalin Matra.

\section{Dimensi Penerima Manfaat}

Pemerintah Provinsi (Pemprov) Jawa Timur untuk program “Jalan Lain Menuju Mandiri dan Sejahtera" (Jalin Matra) menargetkan pada tiga kelompok rumah tangga, yakni pada desil 1, desil 2 dan desil 3. Penelitian ini secara khusus melakukan evaluasi pada program yang menyasar kelompok rumah tangga pada desil 2 dan desil 3, yakni fokus pada program Penanggulangan Kerentanan Kemiskinan (PK2) dengan sasaran rumah tangga dengan status kesejahteraan 11\%-30\% terendah atau disebut dengan istilah Rumah Tangga yang Hampir Miskin (RTHM). Secara ekonomi, RTHM sebenarnya merupakan kategori golongan masyarakat yang masih mampu mencukupi kebutuhan hidupnya secara layak, namun masih rentan mengalami kesulitan ekonomi (keguncangan stabilitas ekonomi) apabila menghadapi kebutuhan ekonomi yang nilainya relatif besar, seperti biaya pengobatan apabila jatuh sakit, biaya sekolah/kuliah untuk anak, terjadi bencana alam, terjadi gagal panen, dan lain sebagainya.

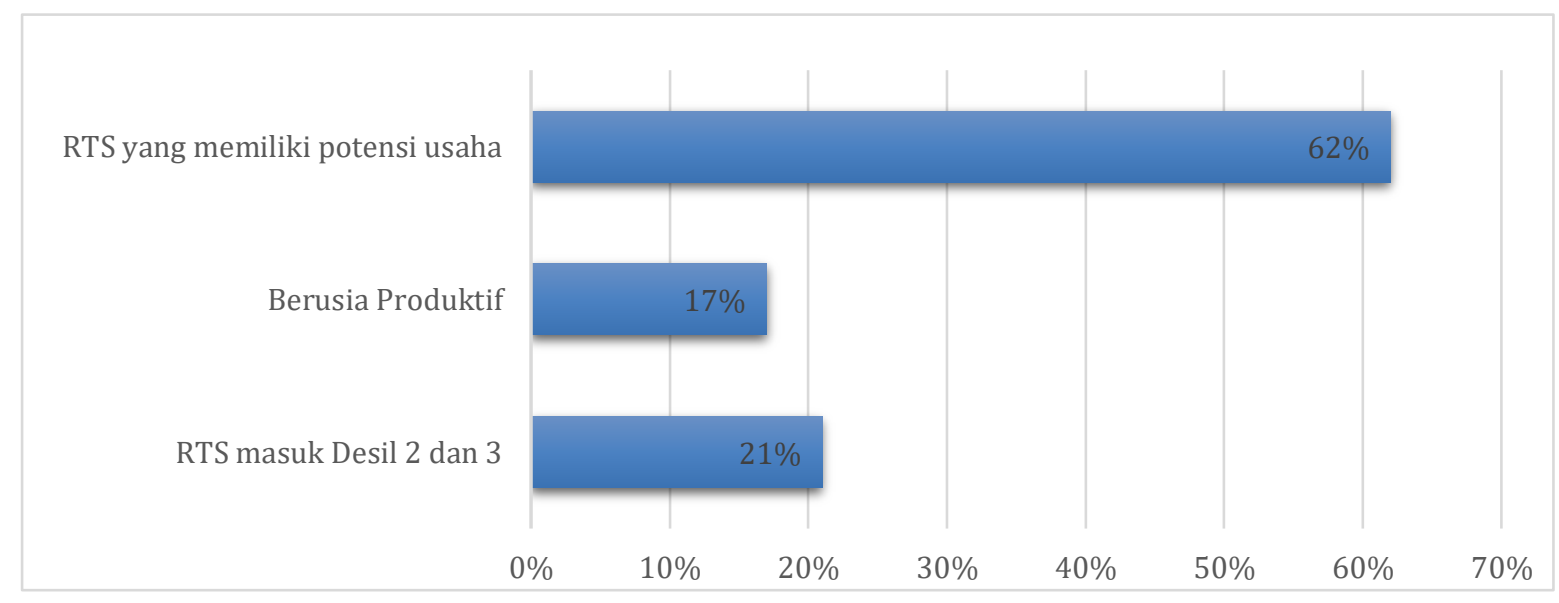

Grafik 1. Kriteria RTS

Sasaran pelaksanaan Pilot Project Jalin Matra PK2 merujuk pada data BPLS 2011. Pada tahap awal diprioritaskan pada Rumah Tangga Sasaran (RTS) dengan tiga kriteria. Kriteria yang paling banyak terpenuhi yaitu Rumah Tangga Sasaran (RTS) yang memiliki potensi usaha mayoritas pilihan responden dengan $62 \%$ Kriteria terbanyak kedua yaitu RTS yang masuk desil 2 dan 3. Kriteria yang paling tidak terpenuhi yaitu penerima program yang berusia produktif sebanyak $17 \%$.

\section{Kriteria dan Karakteristik Desa}

Lokasi Pilot Project Jalin Matra PK2 adalah desa-desa yang berada dalam wilayah Provinsi Jawa Timur dengan empat kriteria seperti di atas. Kriteria yang paling banyak terpenuhi atau yang 
menjadikan desa terpilih yaitu memiliki BUMDesa sebanyak $43 \%$. Kriteria kedua yang paling banyak terpenuhi yaitu desa yang memiliki rumah tangga desil 2 dan desil 3. Kabupaten Malang kriteria yang paling banyak terpenuhi yaitu RTS yang memiliki potensi usaha yaitu sebanyak 96. Kabupaten Madiun kriteria berusia produktif menjadi paling banyak tercapai yaitu $50 \%$. Di Kabupaten Jember, RTS yang memiliki potensi $72 \%$. Kabupaten Sumenep kriteria yang paling banyak terpenuhi yaitu RTS yang memiliki usaha. Jadi tiap daerah memiliki karakteristik penerima masing-masing.

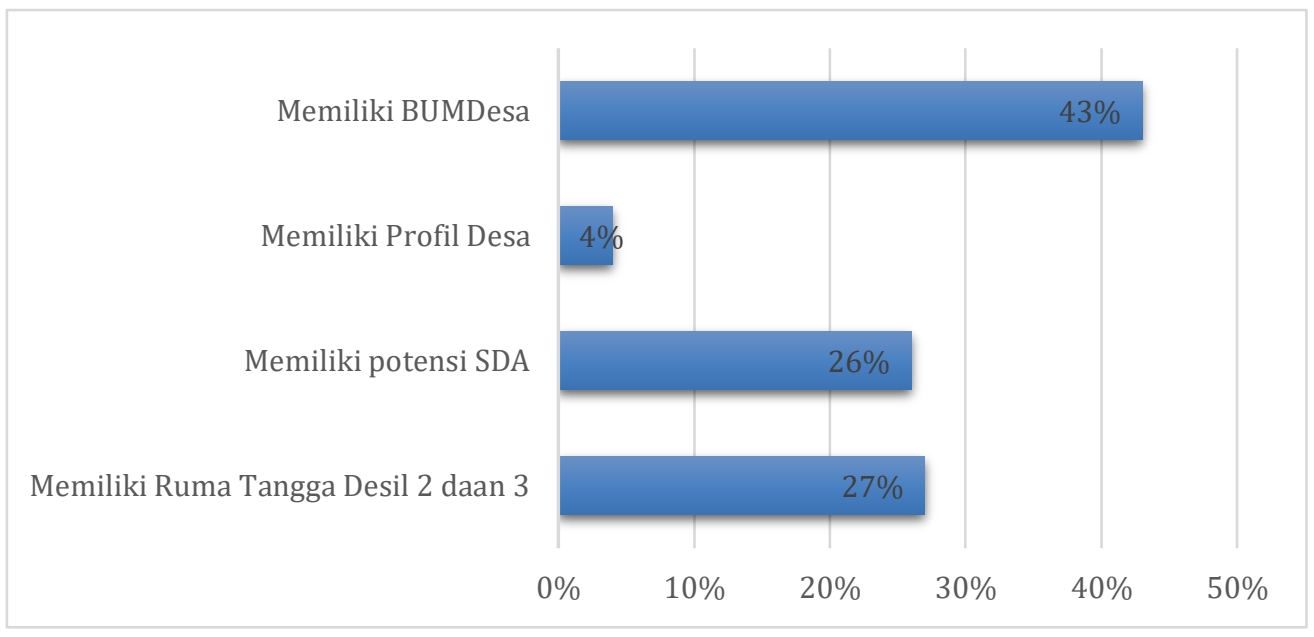

Grafik 2. Kriteria Desa Paling Terpenuhi

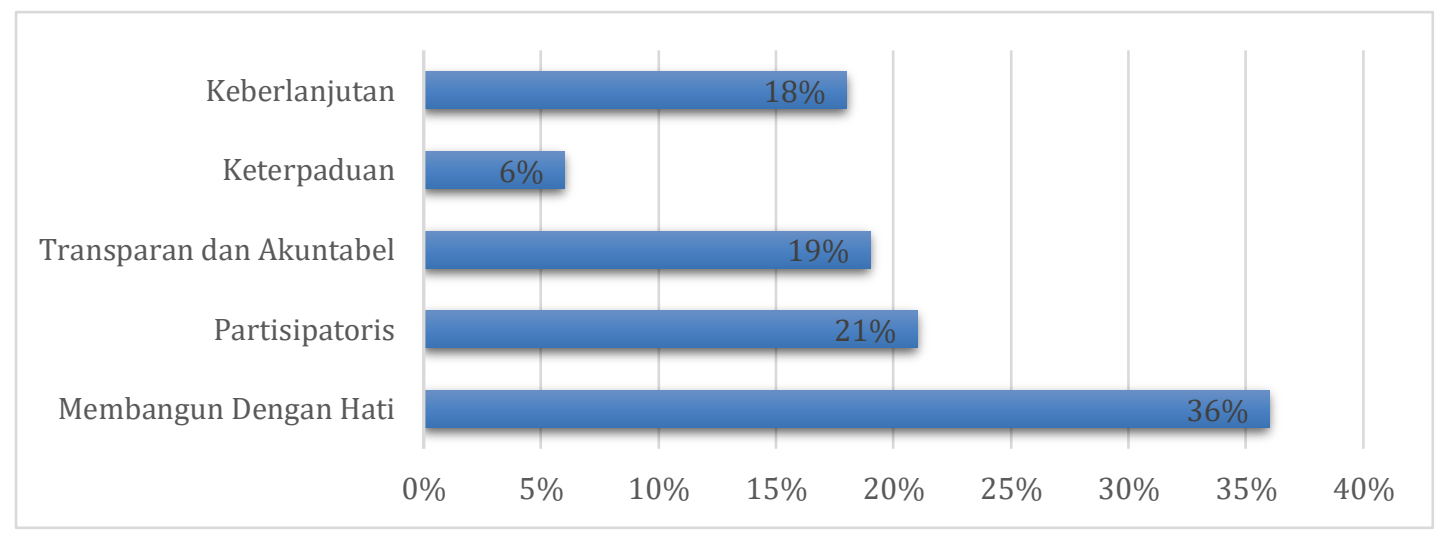

Grafik 3. Kriteria Desa Paling Sesuai

\section{Dimensi Prinsip Pelayanan}

Program Jalin Matra PK2 mempunyai lima prinsip dalam pelaksanaannya, yakni keberlanjutan, keterpaduan, transparan dan akuntabel, partisipatoris, serta membangun dengan hati. Dari kelima prinsip tersebut responden menilai kriteria desa yang paling sesuai semangat Program Jalin Matra PK2 mampu membangun dengan hati yaitu sebesar $36 \%$. Yang kedua responden menilai desa yang mampu melaksanakan program ini dengan melibatkan masyarakat banyak dan stakeholder lain untuk terlibat (partisipatoris) yaitu sebesar $21 \%$. Program ini juga menilai desa harus mampu menerapkan transparansi dan akuntabilitas sebesar $19 \%$. Responden juga menilai program Jalin Matra PK2 mempunyai keberlanjutan program yang baik di desa penerima program yaitu sebesar $18 \%$. Kriteria 
desa yang harus terpenuhi dengan program Jalin Matra PK2 ini di masing-masing daerah berbeda. Misalnya di Kabupaten Malang, kriteria desa yang sesuai paling banyak yaitu membangun dengan hati yaitu sebesar $68 \%$. Di Kabupaten Madiun lebih banyak kriteria transparansi dan akuntabilitas 42,9\%. Di Kabupaten Jember kriteria desa yang paling banyak yaitu keberlanjutan program $36 \%$. Sedangkan di Kabupaten Sumenep kriteria desa yang paling banyak terpenuhi yaitu partisipatoris sebesar $52 \%$.

Evaluasi Program Jalin Matra PK2 secara umum sudah baik, dari responden yang diteliti baik pengguna dan stakeholder yang terlibat mayoritas menyatakan baik yaitu sebesar $54 \%$. Responden juga ada yang menilai program ini sangat baik sebesar $32 \%$, cukup baik $11 \%$ dan hanya $3 \%$ yang menilai program Jalin Matra PK2 kurang baik, 95\% responden juga menilai Program Jalin Matra PK2 berjalan sesuai dengan ketentuan yang ada, dan hanya 5\% responden menilai program PK2 tidak berjalan. Jika dilihat dari penerima program saja, mayoritas masih menilai baik Program Jalin Matra PK2 yaitu sebesar 65,6\%. Penerima program yang menilai sangat baik sebesar 20,3\%, cukup baik 12,5 $\%$, dan hanya $1,6 \%$ penerima menilai program Jalin Matra PK2 kurang baik.

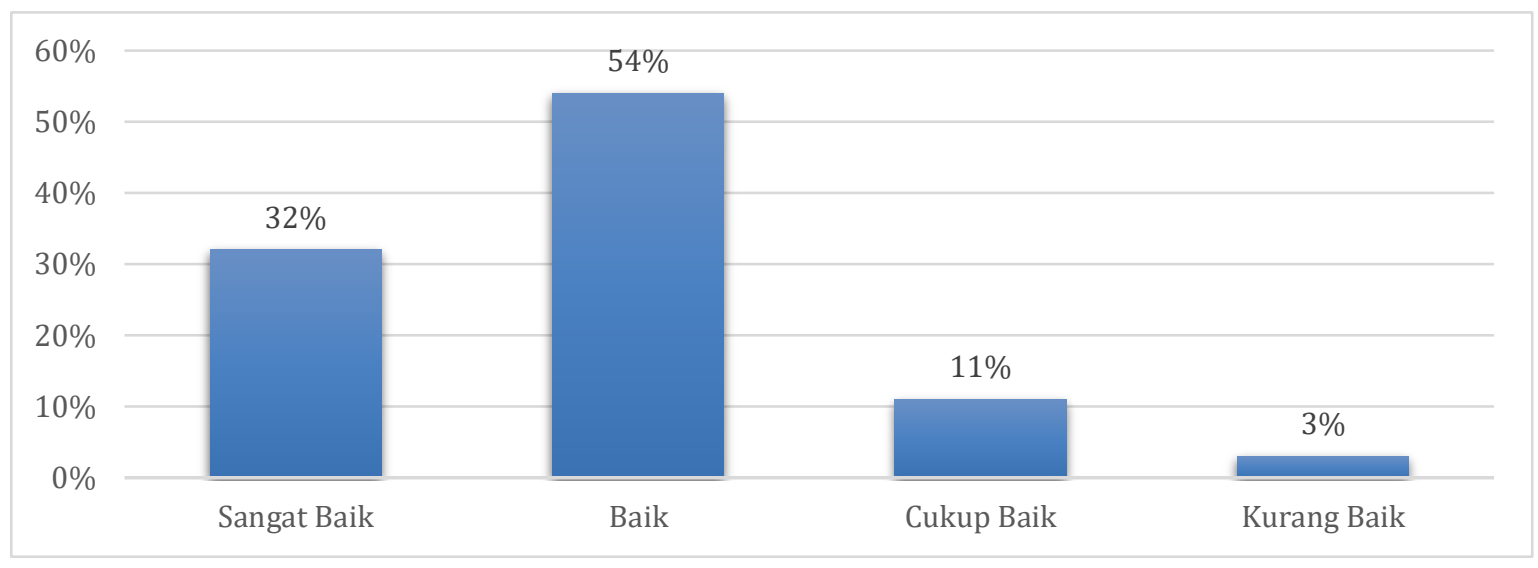

Grafik 4. Evaluasi Program PK2

Ruang lingkup Program Jalin Matra PK2 dinilai oleh responden yang paling terpenuhi yaitu pembentukan/penguatan BUMDesa $41 \%$, terbanyak kedua pengembangan usaha Pokmas sebesar 30 $\%$, dilanjutkan dengan peningkatan kapasitas RTS sebesar $19 \%$ dan yang paling sedikit berkaitan dengan ruang lingkup pendampingan $10 \%$. Jika dilihat di masing-masing daerah seperti di Kabupaten Malang yang paling terpenuhi yaitu pengembangan usaha Pokmas $44 \%$. Di Madiun pembentukan/penguatan BUMdesa sebesar $45 \%$. Di Kabupaten Jember ruang lingkup yang dinilai paling terlaksana yaitu pengembangan usaha Pokmas $36 \%$. Sedangkan di Kabupaten Sumenep ruang lingkup pembentukan/peningkatan BUMDesa. 


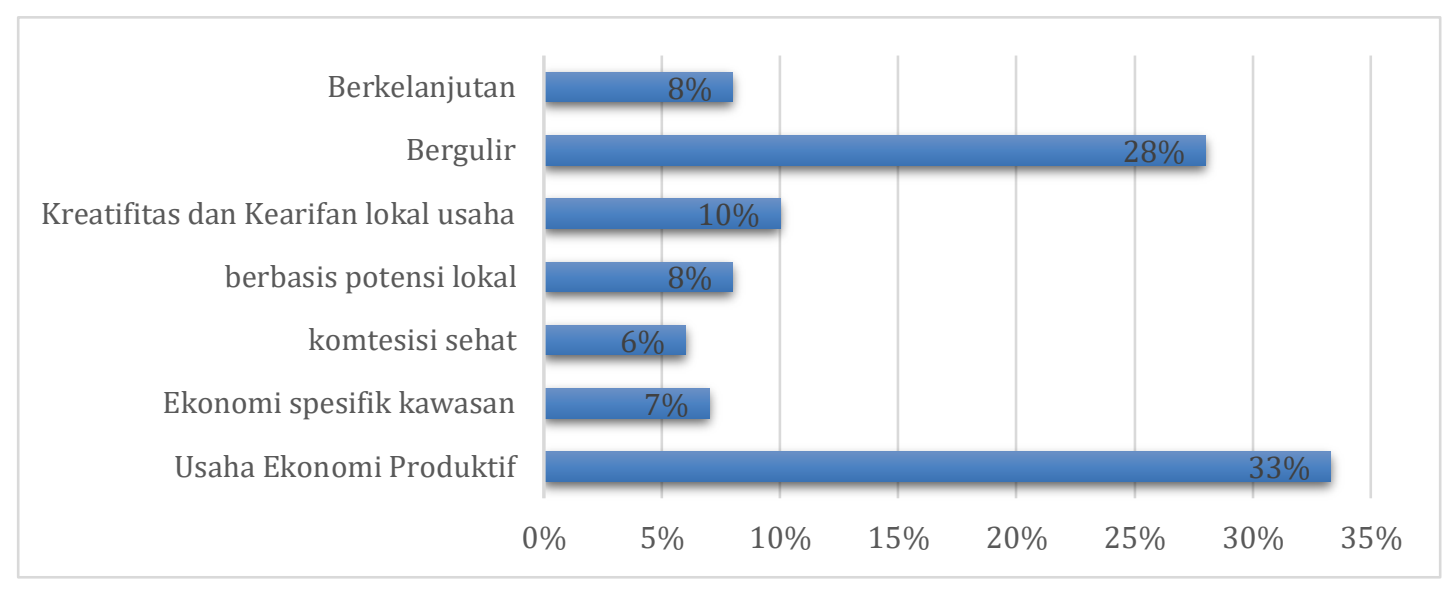

Grafik 5. Ruang Lingkup Paling Terpenuhi

Dari beberapa prinsip pengelolaan Program Jalin Matra PK2 yang paling banyak yaitu usaha ekonomi produktif yaitu sebesar $33 \%$, terbanyak kedua program bantuan yang bergulir $28 \%$. Di Kabupaten Malang prinsip pengelolaan yang paling berjalan yaitu bergulir sebesar $64 \%$. Di Kabupaten Madiun lebih banyak usaha ekonomi produktif 37,5 \%. Sementara itu, di Kabupaten Jember prinsip pengelolaan yang paling berjalan yaitu kreativitas dan kearifan lokal usaha sebesar $36 \%$, sedangkan di Kabupaten Sumenep lebih pada prinsip usaha ekonomi produktif $76 \%$.

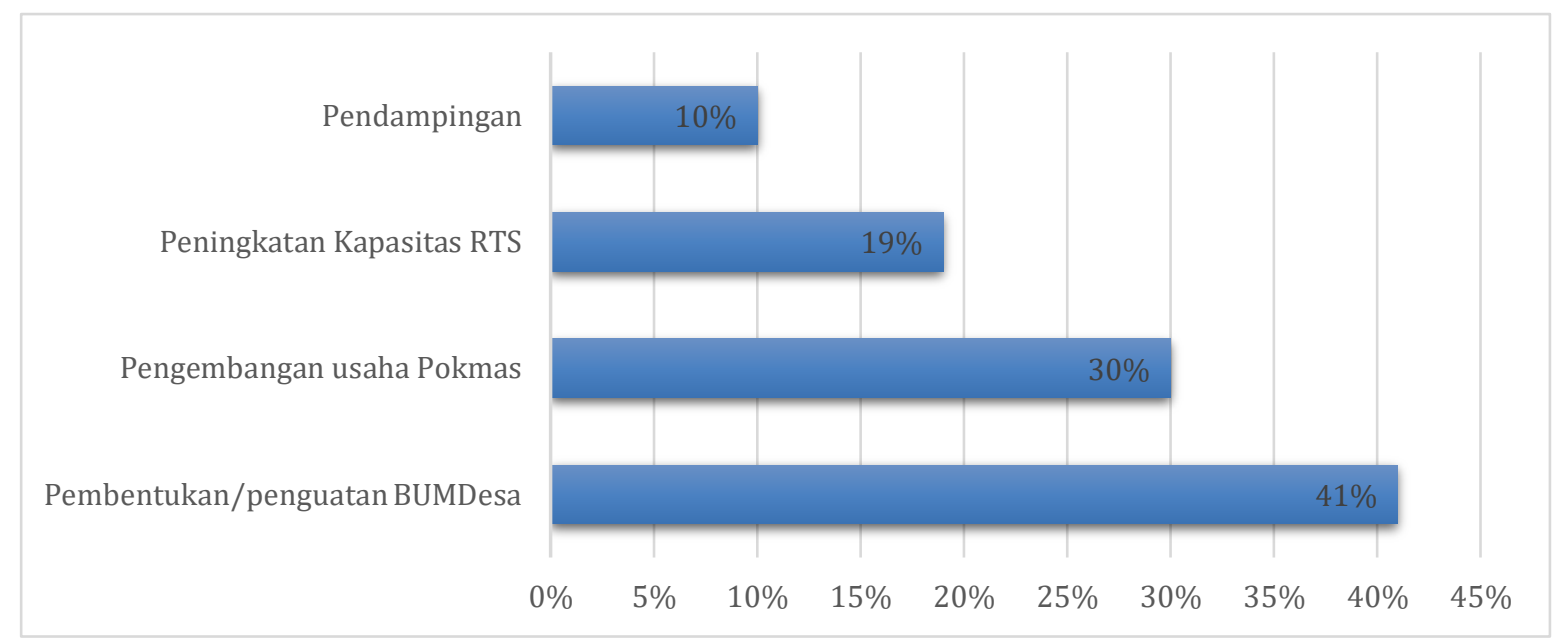

Grafik 6. Prinsip Pengelolaan Paling Berjalan

Usaha ekonomi produktif memiliki ragam bentuk, di antaranya program penggemukan hewan ternak, pembangunan fasilitas umum pendukung perdagangan dan jasa, dana bergulir dan sebagainya. Usaha produktif yang dipilih dimusyawarahkan pada saat rembug desa, sehingga bentuk usaha yang dipilih merupakan ihwal masyarakat desa. Seperti usaha produktif yang ada di desa Banjarsari, Kecamatan Bangalsari, Kabupaten Jember. Program Jalin Matra PK2 di Desa ini berupa program "Gadu Ternak Sapi”. Program ini dilakukan dengan pembelian sapi yang selanjutnya dipelihara oleh PokmasPokmas di bawah naungan BUMDesa. Sapi-sapi yang dipelihara itu pada gilirannya dijual setelah tiga 
bulan berjalan dengan keuntungan (laba) penjualannya dibagi dua, yaitu 50\% laba untuk BUMDes dan $50 \%$ untuk Pokmas pemelihara.

Alasan dibalik penentuan program "Gadu Ternak Sapi" itu utamanya adalah apabila model/strategi Jalin Matra PK2 yang digunakan sama dengan desa-desa yang lain, yakni model simpan pinjam, dikhawatirkan akan sulit untuk angsuran pengembalian pinjamannya dan potensial dipahami oleh masyarakat sebagai "dana hibah" yang tidak wajib dikembalikan. Di samping itu, terdapat pertimbangan bahwa mayoritas penduduk Desa Banjarsari adalah Buruh Kebun PTPN XII Banjarsari dan juga petani, banyak pula yang merantau ke luar negeri sebagai TKI ataupun buruh-buruh kasar di ladang kelapa sawit di Sumatera. Atas dasar itulah akhirnya Desa Banjarsari memilih Penggemukan ternak sebagai usaha BUMDesa yang pengelolaannya dipercayakan kepada Pokmas yang telah dibentuk oleh Kepala Desa maupun perangkat BUMDesa Banjarsari.

Pengguliran perawatan sapi ini tiap tiga bulan dialih-gantikan kepada Pokmas yang lain. Jumlah Pokmas di Desa Banjarsari sebanyak lima Pokmas. Proyeksinya, setelah lima Pokmas sebagai pilot project itu menyelesaikan giliran untuk memelihara dan mendapatkan keuntungan untuk membeli sapi baru untuk dipelihara sendiri terlepas dari tanggungan sapi milik BUMDesa tersebut, maka pihak Pemerintah Desa akan membentuk Pokmas-Pokmas baru, dan begitu seterusnya. Harapannya, program "Gardu Ternak Sapi"

itu bergulir dari satu Pokmas ke Pokmas lain sehingga secara tidak langsung masyarakat Desa Banjarsari

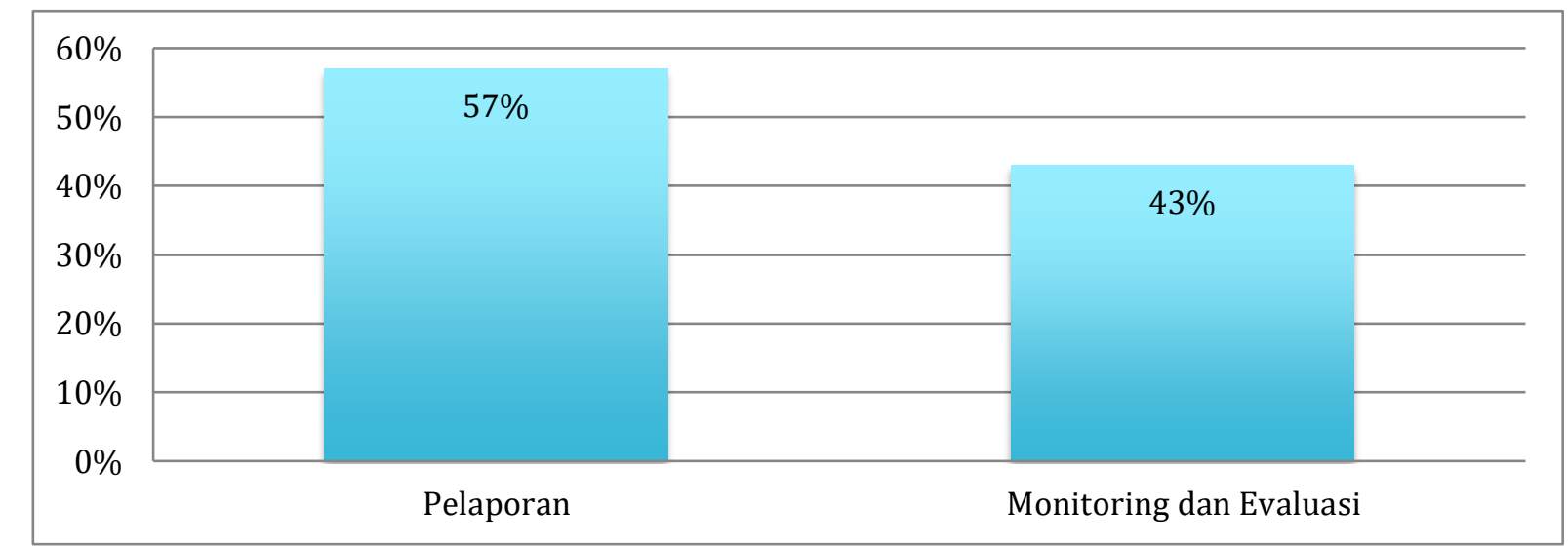

merasakan manfaatnya.

Grafik 7. Pengendalian Paling Sulit

Usaha penggemukan hewan ternak juga dipilih oleh desa Kuwu, Kecamatan Balerejo, kabupaten Madiun. Dalam rembug desa, masyarakat desa Kuwu menyepakati untuk menggunakan anggaran dana bantuan Jalin Matra berupa ternak kambing yang diatur dalam tiap kelompok masyarakat (Pokmas). Kelompok masyarakat dibentuk berdasarkan jumlah dusun di desa Kuwu sendiri yaitu sebanyak 5 dusun. Teknisnya, tiap-tiap kelompok masyarakat akan mendapat bantuan yang besaran sudah disepakati sebelumnya. Tiap Pokmas di desa ini mendapat bantuan dana yang sama yaitu Rp 15.000.000,-, dengan tiap kelompok masyarakat beranggotakan 10 orang. Sesuai dengan kesepakatan 
rembug masyarakat desa untuk menjaga asas keberguliran dana bantuan ini, maka diputuskan untuk dibagi Rp 1.500.000,-/anggota Pokmas (RTS) dan dirupakan menjadi satu ekor kambing betina.

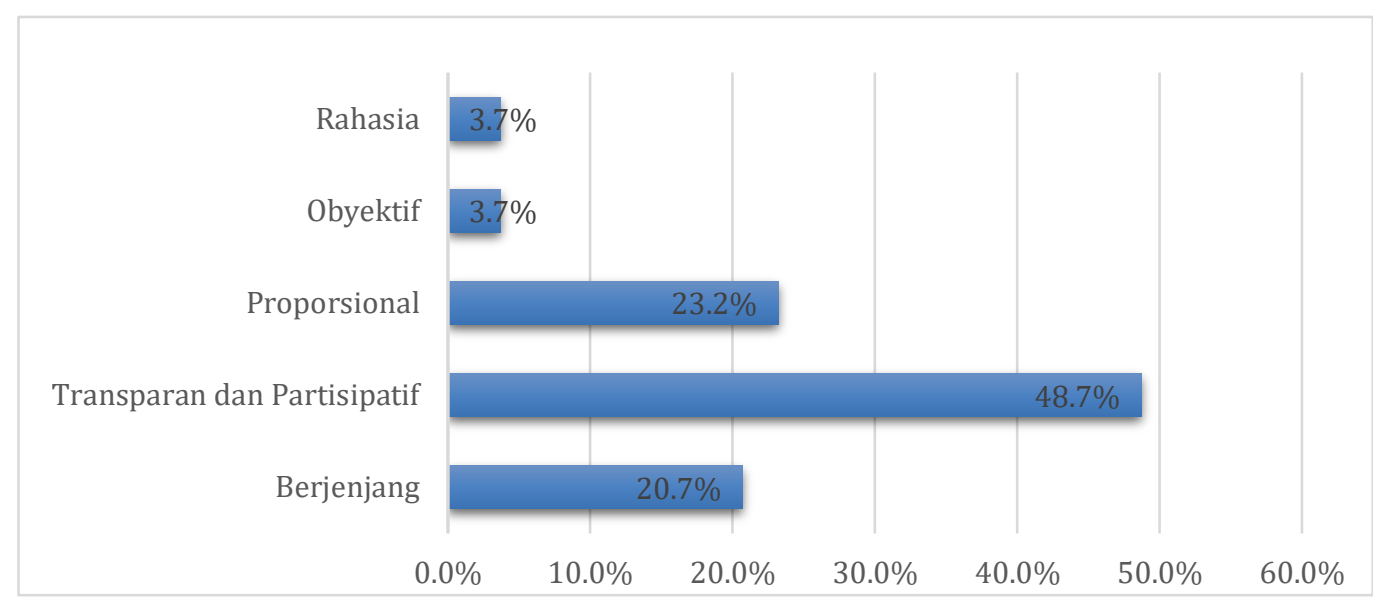

Grafik 8. Prinsip Penanganan Masalah

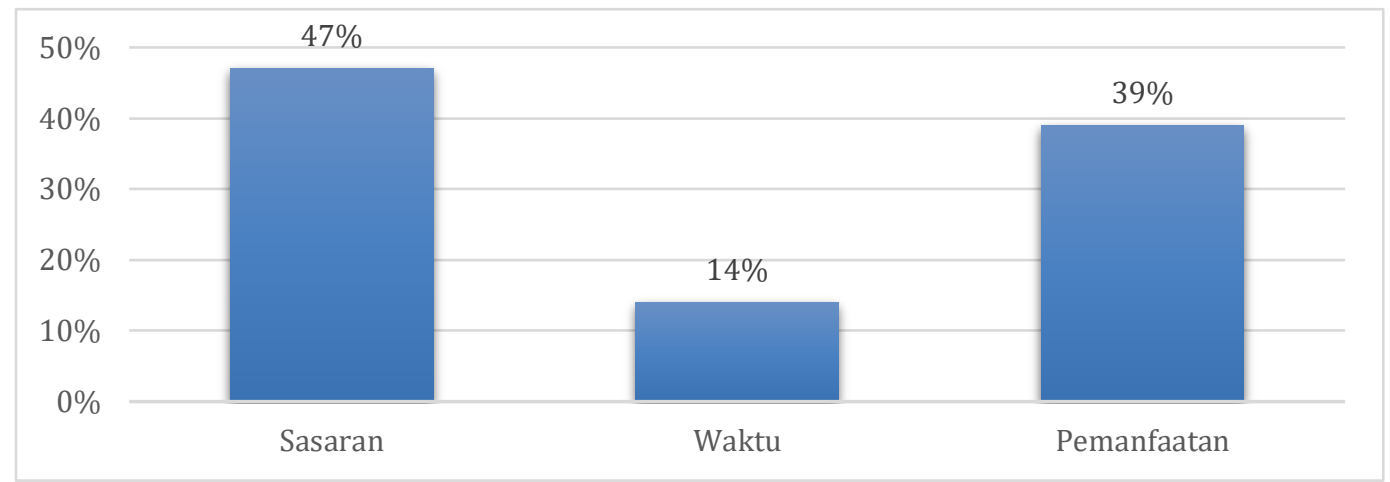

Grafik 9. Komponen Paling Terlaksana

Dalam pelaksanaan program Jalin Matra PK2 khususnya berkaitan dengan pengendalian yang dinilai paling sulit yaitu pelaporan yaitu sebesar 57\%, sedangkan monitoring dan evaluasi hanya $43 \%$. Secara umum dengan melihat latar belakang penerima program maka memang perlu pendampingan tersendiri terhadap pembuatan laporan yang benar sesuai dengan ketentuan yang ada. Dari empat kabupaten yang diteliti untuk kesulitan pelaporan paling banyak dikeluhkan di Kabupaten Jember yaitu sebesar 42,1\%. Sedangkan untuk monitoring dan evaluasi banyak dikeluhkan di Kabupaten Sumenep yaitu sebesar $45,2 \%$. Sehingga untuk program selanjutnya masing-masing daerah perlu penguatan atau pendampingan yang berbeda-beda, sesuai dengan kebutuhan dan karakteristiknya.

Dalam pelaksanaan Program Jalin Matra PK2 ketika ada permasalahan ada lima prinsip yang harus dilakukan: berjenjang, transparan dan partisipatif, proporsional, obyektif dan rahasia. Secara umum prinsip yang paling banyak dilaksanakan yaitu transparan dan partisipatif $48,7 \%$. Prinsip proporsionalitas terbanyak kedua $23,2 \%$. Prinsip lainnya yang terlaksana jika ada permasalahan yaitu berjenjang 20,7\%. Kabupaten Malang, Kabupaten Madiun, dan Kabupaten Jember paling banyak sudah menerapkan prinsip transparan dan partisipatif. Kabupaten Malang sebesar 52\%, Kabupaten Madiun 
58\%, Kabupaten Jember 36\%. Kabupaten Sumenep prinsip yang paling banyak dilakukan yaitu berjenjang dan proporsional masing-masing $32 \%$.

Komponen yang paling tercapai dari pelaksanaan Program Jalin Matra PK2 yaitu sasaran sebesar 47\%, pemanfaatan 39\%, dan waktu 14\%. dari keempat kabupaten yang diteliti hanya Kabupaten Malang komponen paling terlaksana adalah pemanfaatan sebesar 56\%. Sedangkan ketiga kabupaten lainnya sama, komponen sasaran paling banyak terpenuhi. Kabupaten Madiun 45,5\%, Kabupaten Jember $48 \%$ dan Kabupaten Sumenep 64\%.

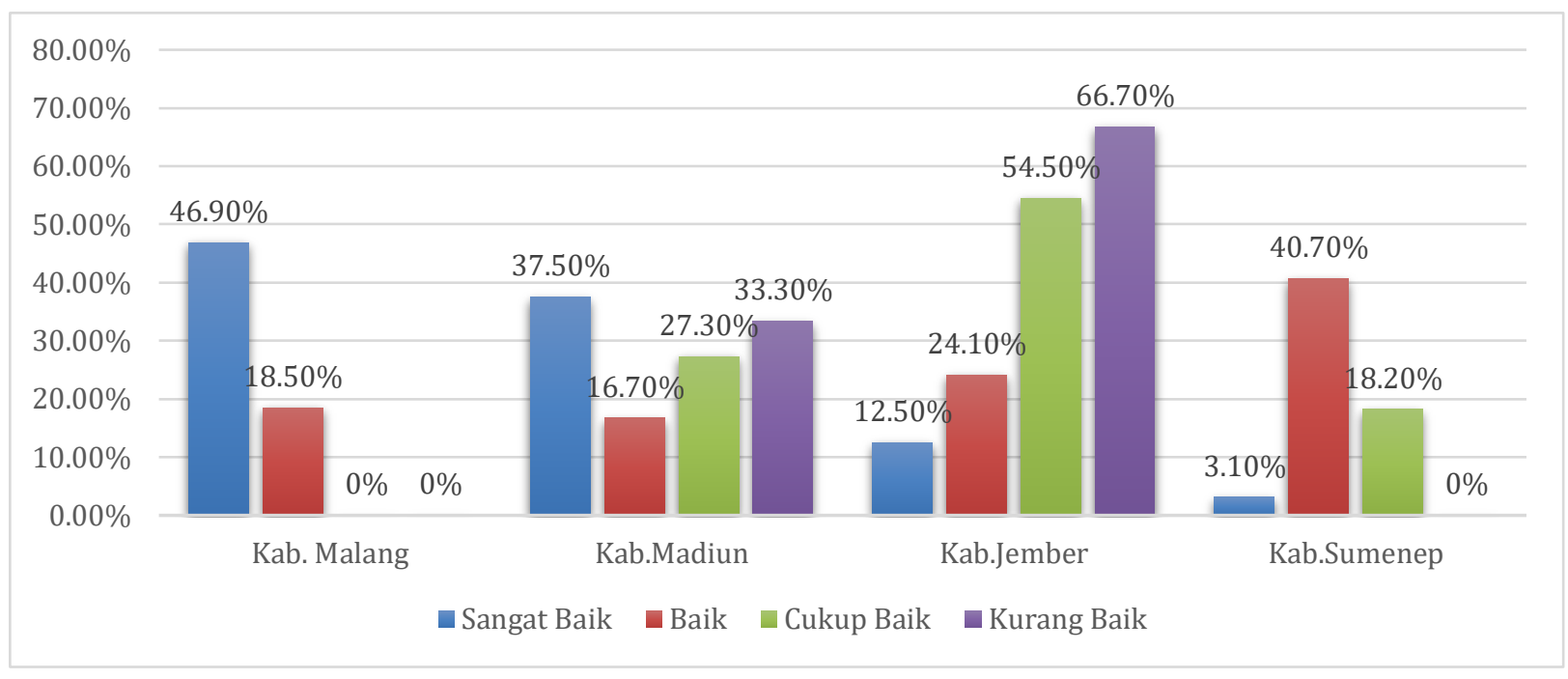

Grafik 10. Evaluasi Program PK2 Tiap Kabupaten

Pelaksanaan Program Jalin Matra PK2 pelaksanaan sangat baik paling tinggi di Kabupaten Malang yaitu sebesar 46,9\%. Pelaksanaan Program Jalin Matra PK2 di Kabupaten Malang memang benar-benar bisa mengurangi ketergantungan terhadap rentenir. Pelaksanaan Program Jalin Matra PK2 sangat baik setelah Kabupaten Malang yaitu di Kabupaten Madiun sebesar 37,5\%. Sedangkan di Kabupaten Jember yang menilai sangat bagus hanya $12,5 \%$ dan yang paling rendah di Kabupaten Sumenep hanya $3,1 \%$.

Responden yang menilai baik pelaksanaan Program Jalin Matra PK2 paling tinggi Kabupaten Sumenep 40,70 \%, terbaik kedua Kabupaten Jember 24,10\%, Kabupaten Malang 18,50\% dan Kabupaten Madiun 16,70\%. Kabupaten Jember perlu mendapatkan perhatian, karena pelaksanaan Program Jalin Matra PK2 dinilai kurang. Responden yang menilai cukup baik tertinggi di Kabupaten Jember yaitu mencapai 54,5\%. Sedangkan yang menilai kurang baik justru lebih tinggi mencapai $66,7 \%$ (dari total responden yang menilai kurang baik) atau $8 \%$ dari seluruh responden di Kabupaten Jember. Walaupun hanya $8 \%$ namun dibandingkan dengan kabupaten lainnya paling tinggi. Kalau dilihat responden khusus di Kabupaten Jember mayoritas menilai baik sebesar 52\%, cukup baik 24\%, sangat baik $16 \%$ dan kurang baik $8 \%$. 


\section{Kendala Dalam Implementasi Program PK2 di Lokasi Penelitian}

Program Jalin Matra PK2 dalam pelaksanaannya juga mengalami kendala, kendala yang paling banyak yaitu klarifikasi RTS sebesar $22 \%$. Kendala terbanyak kedua yaitu verifikasi dan penilaian kelayakan usaha mencapai $12 \%$. Kendala ketiga yaitu bimbingan teknis sebesar $10 \%$. Realisasi dan pertanggungjawaban juga menjadi kendala dalam pelaksanaan program, masing-masing sebanyak $6 \%$ responden. Identifikasi potensi desa dan penyusunan rencana usaha Pokmas juga masih menjadi kendala, masing-masing $5 \%$ responden menilai hal tersebut.

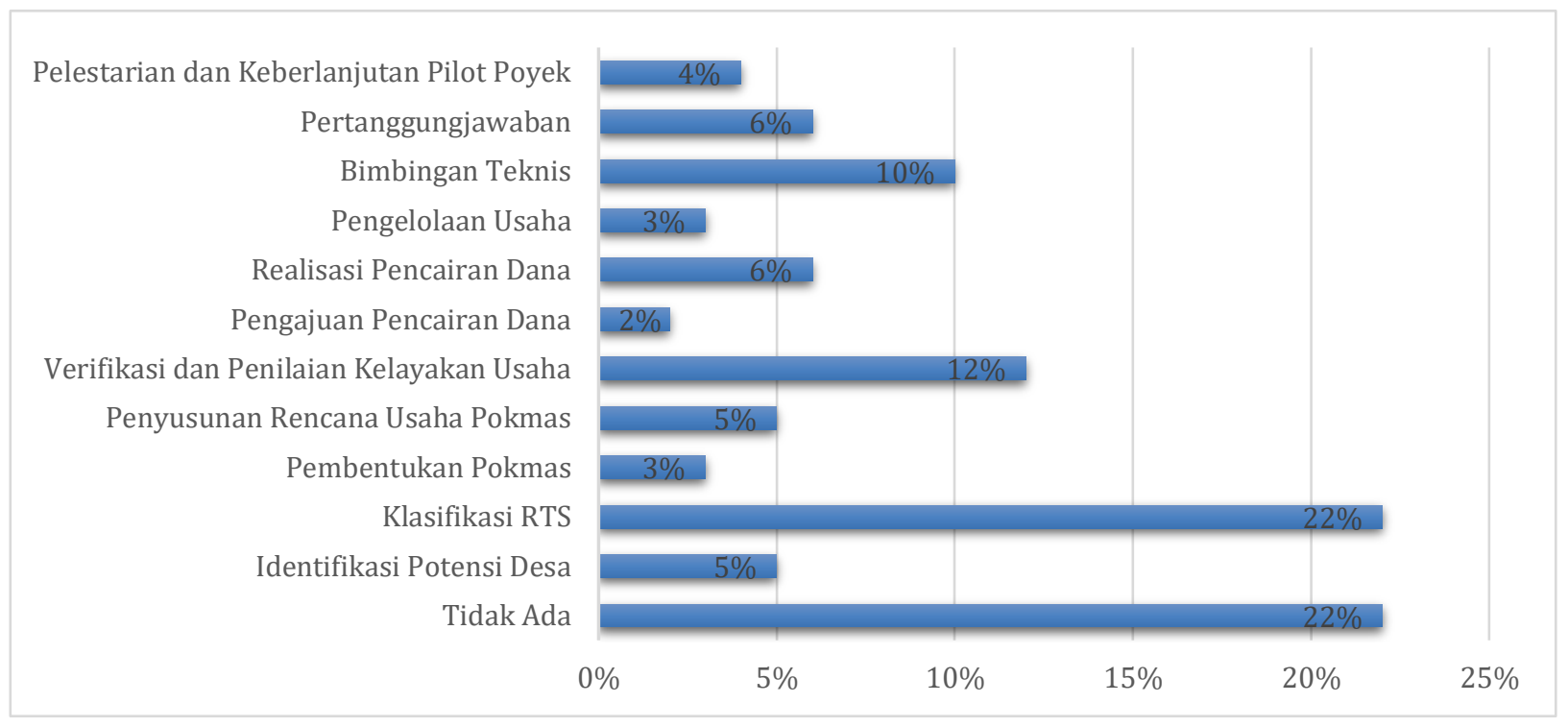

Grafik 11. Kendala Implementasi Program PK2

\section{Kendala Identifikasi Rumah Tangga Sasaran}

Jika dilihat di masing-masing kabupaten kendala yang dihadapi berbeda-beda. Kendala di Kabupaten Malang mayoritas klarifikasi RTS yaitu $16 \%$. Seperti yang diungkapkan oleh Sumaryono Ketua BUMDES Sindurejo; "kami mengalami kesulitan saat menentukan RTS program ini, sebab dari daftar yang dikeluarkan Pemprov (Bappemas), kondisinya sudah tidak sesuai lagi di lapangan, yang ada di daftar tersebut banyak yang belum punya usaha, jadi tidak masuk kriteria program ini, sedangkan kami sebagai pihak pengelola BUMDES kurang berani menyalurkan bantuan ini kepada warga lain yang tidak ada di daftar tersebut meskipun dia memenuhi syarat untuk memperoleh bantuan program ini." Sumber data kemiskinan yang dirujuk Bappemas sudah banyak yang berubah di lapangan, sehingga hal ini menyulitkan pengelola dalam menentukan sasaran program ini. Solusi yang diambil oleh pengelola adalah dengan menetapkan sasaran program sesuai data Bappemas pada tahun pertama pelaksanaan program. Sedangkan untuk perguliran selanjutnya mereka menggunakan data berdasarkan realitas yang terjadi saat ini.

Penentuan RTS juga menjadi masalah di Desa Pandansari Kecamatan Poncokusumo Kabupaten Malang. Permasalahan yang cukup merisaukan adalah tentang validitas data penerima program yang dikeluarkan Bappemas. Menurut Kepala Desa, pemerintah desa sudah mengirimkan data terbaru 
mengenai klasifikasi warga, namun data yang turun kepada mereka tetap saja data lama yang belum diperbarui. Menurut Ketua BUMDes setempat, dari 1.181 orang yang ada dalam data tersebut hanya 90 orang yang terserap dalam program Jalin Matra ini. Hal ini disebabkan dua hal, pertama warga yang memenuhi syarat tidak mau memanfaatkan program Jalin Matra tersebut, dan kedua, sebagian besar sudah tidak lagi memenuhi syarat sebagai sasaran penerima program ini. Oleh karena itu, pengelola program mengambil langkah pada tahun pertama sasaran penerima program sesuai data yang dikeluarkan Bappemas (tanpa verifikasi), sedang tahun kedua mereka melakukan seleksi dan verifikasi sendiri agar sesuai secara faktual dengan kondisi masyarakat yang membutuhkan program ini.

Hal senada juga terjadi di Kabupaten Madiun, kendala yang paling banyak yaitu klarifikasi RTS sebanyak $40 \%$. Sedangkan kendala di Kabupaten Jember ada dua kendala: 1) verifikasi dan penilaian kelayakan usaha sebesar $24 \%$, 2) realisasi pencairan dana sebesar $24 \%$.

Di Kabupaten Sumenep ada empat kendala masing-masing $20 \%$ yaitu klarifikasi RTS, penyusunan rencana usaha Pokmas, bimbingan teknis dan pertanggungjawaban. Data tersebut juga diperkuat dengan temuan data kualitatif yang didapatkan dengan indepth interview. Kesulitan utama pengurus Bumdesa yang berhasil kami catat ketika melakukan observasi di Desa Pakondang, Kecamatan Rubaru adalah dalam menetapkan Rumah Tangga Sasaran (RTS). Pengelola program Jalin Matra di desa ini belum mampu secara cermat mengklasifikasi sasaran utama dari program ini, yaitu Keluarga Rentan Miskin. Hal ini disebabkan tidak adanya sistem administrasi kependudukan atau database mengenai klasifikasi tingkat kesejahteraan penduduk di desa ini, sehingga penetapan sasaran dalam penyaluran kredit program ini tidak memiliki basis klasifikasi yang benar sesuai petunjuk teknisnya.

\section{Kendala Standar Pelayanan Publik Pemerintah Desa}

Menurut pengamatan kami, kendala utama dari efektivitas pelaksanaan program Jalin Matra adalah kurangnya dukungan teknis administratif yang memadai, problem ini sangat mengemuka terutama di kabupaten Sumenep. Tidak seperti pada BUMDes, di beberapa desa yang ada di kabupaten Malang misalnya, desa di kabupaten Sumenep memiliki problem yang serius berkaitan dengan standar pelayanan publik. Gejala umum pelayanan publik yang ada di Sumenep secara administratif belum memadai, baik dari segi infrastruktur seperti kantor balai desa, sarana dan prasarana penunjang. Di sisi lain program Jalin Matra bisa berjalan baik jika ada topangan dari kinerja pelayanan publik yang baik di tingkat desa. Tidak terstandarnya pelayanan publik di tingkat desa, berdampak pada efektivitas program Jalin Matra. Hal ini tidak terlepas, berhasil atau tidaknya program Jalin Matra PK2 sangat dipengaruhi oleh kinerja kepengurusan BUMDES sebagai ujung tombak program PK2, di sisi lain baik dan buruknya kinerja BUMDesa juga sangat dipengaruhi oleh faktor kepemimpinan politik pemerintah desa.

\section{Upaya Mengatasi Kredit Macet untuk Menjamin Keberlanjutan Program}

Dalam rangka menjaga keberlanjutan program ini, maka pengelola program harus bisa menjaga kelancaran pengembalian pinjaman. Untuk itu, pengurus Bumdesa melakukan upaya-upaya, antisipatif seperti adanya pertemuan rutin di antara para penerima program Jalin Matra. Pertemuan rutin itu diisi 
dengan arisan yang hasilnya bisa menambah permodalan dalam kegiatan mereka. Selain itu, untuk menjaga kedisiplinan dalam membayar cicilan, maka dilakukan sistem "tanggung-renteng", yaitu apabila ada salah satu anggota kelompok yang tidak bisa membayar, maka seluruh anggota Pokmas ikut serta menanggung beban dari anggota yang tengah mengalami kesulitan pembayaran cicilan tersebut. Dengan demikian, maka mereka akan saling mengingatkan dan saling memotivasi satu sama lain agar tidak sampai menunggak cicilan. Strategi ini untuk sementara waktu berhasil meminimalisir adanya kredit macet pada program ini, sehingga program ini bisa berjalan lancar dan terus bergulir ke orang lain yang juga membutuhkan.

Sistem Tanggung renteng juga diaplikasikan di Desa Sindurejo, Kabupaten Malang dan juga terbukti efektif untuk menekan kredit macet. Seperti yang dituturkan oleh Bapak Sumaryono selaku Ketua Unit Pelaksana Jalin Matra Bumdes Sindurejo; "untuk meminimalisir kredit macet, kami pengelola menerapkan ketentuan adanya tanggung renteng sesama anggota Pokmas. Selain bertujuan untuk meminimalisir kredit macet, ketentuan tanggung renteng ini juga ditujukan agar terjadi komunikasi dan berbagi informasi antar sesama anggota Pokmas agar usaha masing-masing anggota berjalan lancar, sehingga tidak membebani anggota yang lain."

Tantangan terhadap keberlanjutan program juga terletak pada upaya "mangkir" yang dilakukan oleh masyarakat penerima program. Jika dalam kasus kredit macet masih memiliki upaya untuk mengembalikan dana pinjaman, namun ada sesuatu hal seperti kerugian, bencana lama seperti yang dialami masyarakat Madiun dan jember saat meletusnya Gunung Kelud, namun di luar itu ada upaya dengan sengaja yang tidak berkeinginan untuk mengembalikan dana sedari awal ketika program ini bergulir. Seperti yang dituturkan oleh Kepala Desa Juluk, Kecamatan Saronggi, Kabupaten Sumenep; "program ini sangat bagus bagi masyarakat. Masyarakat yang awalnya mengalami kesulitan dalam menjalankan usahanya menjadi terangkat kembali karena ada penambahan modal usaha dari program ini. Hanya saja, menurut kepala desa, timbal balik dari masyarakat penerima program kurang bagus. Mereka kurang disiplin dalam mengembalikan pinjaman akibat provokasi dari sebagian pihak yang menyatakan bahwa program ini adalah HIBAH. Bahkan mereka juga diprovokasi bahwa apabila dana pinjaman itu dikembalikan, maka nantinya akan dimakan (baca: dikorupsi) oleh pengurus (pelaksana program).

Saat kami tanyakan mengenai upaya-upaya pengurus atau pelaksana program terhadap masalah ini, Kepala desa mengatakan bahwa pihak penyelenggara maupun pihak aparat desa hanya bisa melakukan upaya-upaya persuasif demi menjaga ketertiban desa. Pihak pemerintah desa kurang berani bersikap tegas karena menyangkut aspek politik di tingkat desa.

Dari hasil pembicaraan kami dengan pihak pemerintah desa, kami menyimpulkan dari apa yang tersirat, bahwa di satu sisi, pihak pelaksana program dan pemerintah desa merasa ewuh pekewuh dengan urusan pengembalian pinjaman ini karena ada agenda politik, di mana apabila mereka melakukan penagihan atau pengaturan secara tegas nanti akan berpengaruh terhadap mobilisasi suara terhadap 
pihak mereka. Di sisi lain, masyarakat penerima program juga sadar dengan agenda tersebut dan akhirnya menjadikan masalah ini sebagai bargaining politik terhadap pihak pemerintah desa.

Hal tersebut diakui oleh kepala desa, sehingga mereka saat ini tengah menyusun rencana-rencana baru agar sebisa mungkin terjadi perguliran kepada masyarakat lain sehingga bisa terjadi pemerataan kepada sebanyak mungkin masyarakat yang membutuhkan. Selain itu, pihak pelaksana program juga berharap ada penambahan dana Jalin Matra kepada desa mereka agar mereka bisa merestrukturisasi program yang terancam gagal tersebut.

\section{Honorarium Pengurus BUMDES Pelaksana Program Jalin Matra}

Belum adanya gaji khusus untuk pengelola program Jalin Matra. Hal ini disiasati dengan menyisihkan dari sisa hasil usaha BUMDES. Seperti yang terjadi di Desa Pandansari, Kecamatan Poncokusumo, Kabupaten Malang, gaji atau honorarium pengelola BUMDES belum diatur. Menurut Bendahara BUMDes, selama ini mereka bekerja keras tanpa gaji atau honor yang memadai, sebab mereka hanya mendapatkan semacam fee dari SHU program ini. Pada tahun pertama BUMDES berhasil mengumpulkan SHU sebesar Rp.3.900.000,- sedang pada semester pertama tahun 2016 ini sudah berhasil mengumpulkan SHU sebesar Rp.12.000.000,-. Dari besaran dana SHU tersebut, mesti dialokasikan juga untuk pengadaan inventaris yang bisa menunjang kinerja pengurus dalam operasional program ini, seperti laptop dan kelengkapan kantor lainnya.

\section{Dimensi Sumber Daya}

Pada dimensi analisis sumber daya, evaluasi ditekankan pada bagaimana sumberdaya yang telah dialokasikan oleh pemerintah bisa memiliki dampak pada pemecahan masalah, dalam kontek Jalin Matra, sumberdaya tersebut diharapkan bisa menjadi pengukit kesejahteraan masyarakat penerima manfaat. Program Jalin Matra PK2 secara umum oleh responden dinilai mampu meningkatkan pendapatan. Sebesar $63 \%$ responden menilai dengan program Jalin Matra PK2 pendapatan meningkat. Responden yang menilai cukup meningkat sebanyak $23 \%$, sangat meningkat $8 \%$ dan kurang meningkat hanya $6 \%$. 


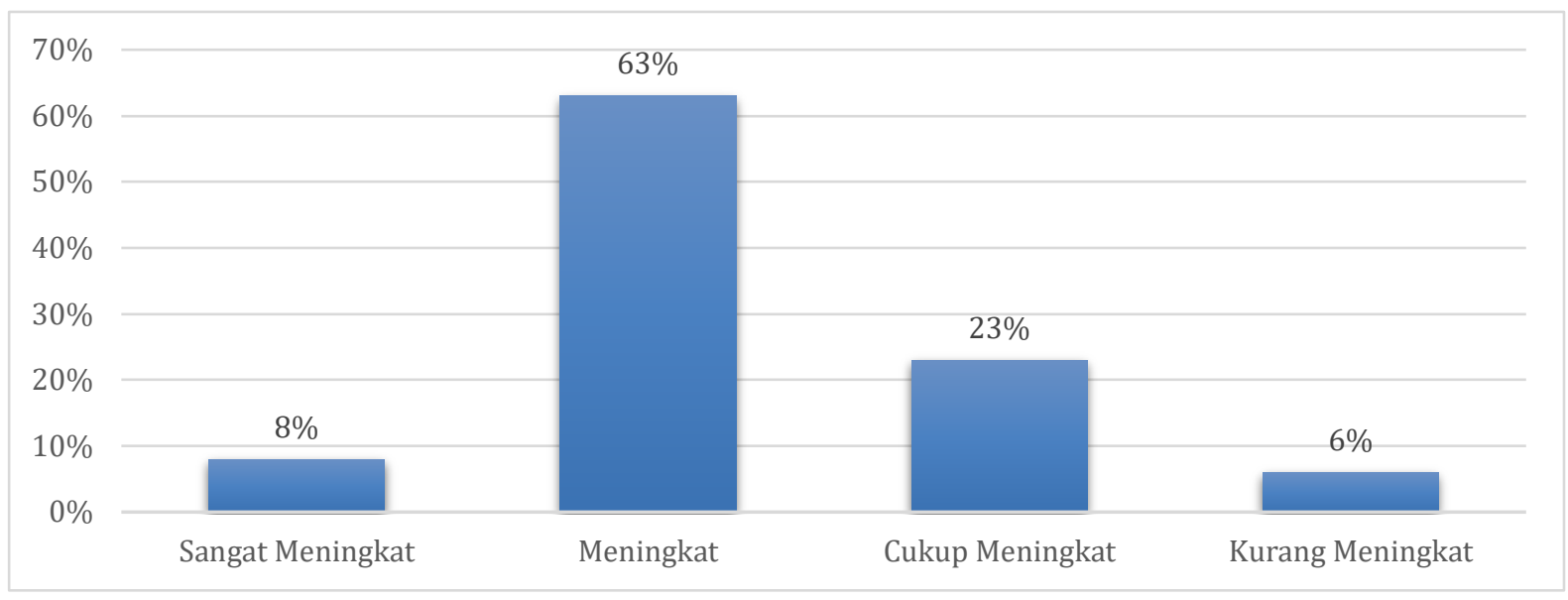

Grafik 12. Dampak terhadap Peningkatan Pendapatan

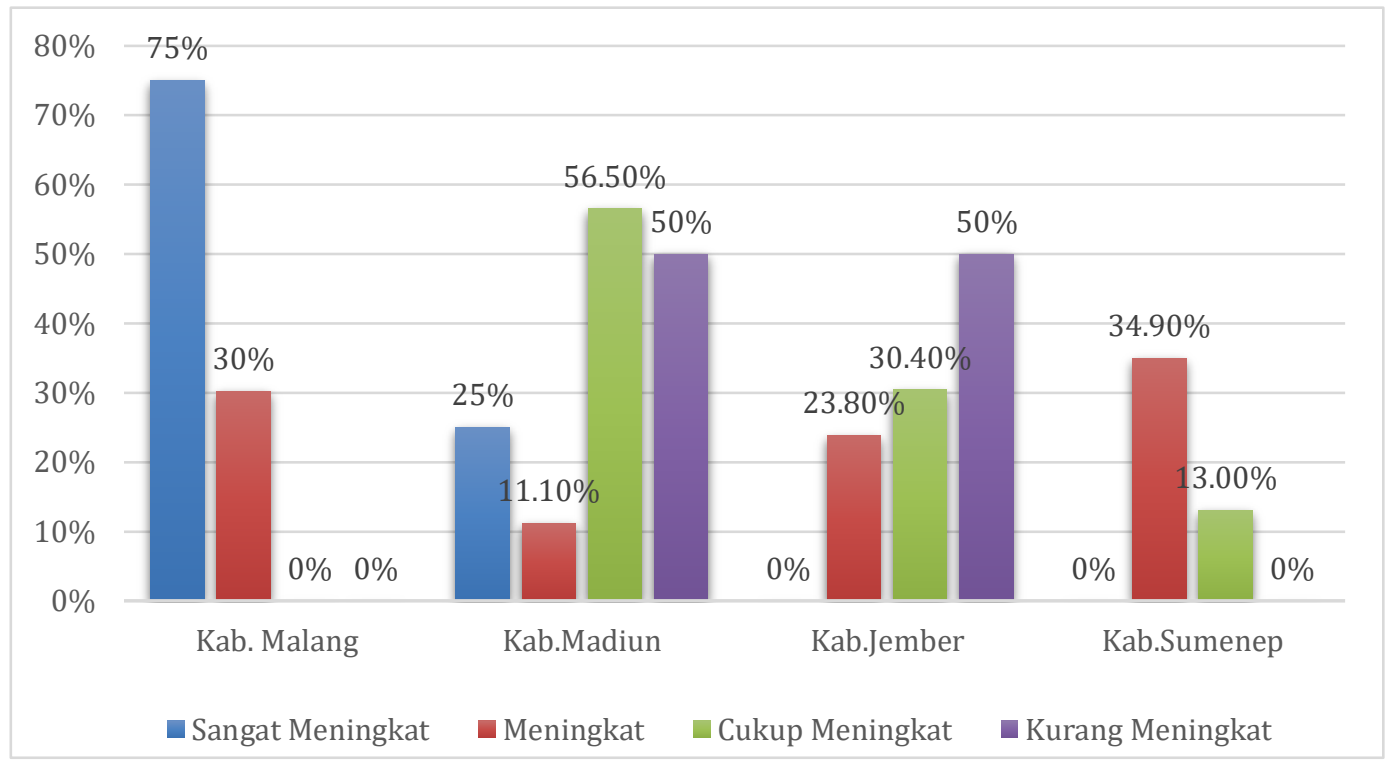

Grafik 13. Dampak Implementasi Program

Jika dilihat dari diagram di bawah pelaksanaan program Jalin Matra PK2 yang memberikan dampak sangat meningkat paling tinggi di Kabupaten Malang yaitu mencapai $75 \%$, sedangkan di Kabupaten Jember hanya $25 \%$. Responden yang menilai meningkat paling tinggi di Kabupaten Sumenep 34,9\%. Data yang ditunjukkan Kabupaten Sumenep berbanding lurus dengan data kualitatif yang kami dapatkan, Adapun dampak sosial-ekonomi dari program ini sebenarnya cukup signifikan. Masyarakat yang semula kesulitan penambahan modal usaha dapat tertangani dengan adanya program ini. Demikian pula sebagian masyarakat yang awalnya belum punya usaha menjadi punya usaha dengan bantuan modal dari program Jalin Matra ini. Sehingga kami bisa menarik kesimpulan bahwa program ini bisa meningkatkan peluang meningkatnya pendapatan dan kesejahteraan masyarakat di desa Larangan Kerta ini.

Sisi menarik lainnya yang dapat kami temukan selama observasi lapangan adalah adanya kelompok masyarakat (Pokmas) yang melakukan usaha bersama. Modal yang mereka peroleh dari 
bantuan program ini dikumpulkan menjadi satu kemudian melakukan usaha bersama berupa penyewaan alat-alat pesta, seperti piring, gelas, meja, kursi, dan sebagainya dengan bimbingan dari salah seorang yang sudah menekuni usaha ini sebelumnya. Dengan demikian, omzet usaha menjadi lebih besar dan pelayanannya pun menjadi lebih baik, sehingga memperlancar gerak operasional usaha tersebut.

Tertinggi kedua Kabupaten Malang $30 \%$, tertinggi ketiga Kabupaten Jember 23,80\% dan paling rendah Kabupaten Madiun hanya 11,10 \%. Responden yang menilai cukup paling tinggi di Kabupaten Madiun 56,50 \%. Sedangkan responden yang menilai kurang meningkat paling banyak di Kabupaten Madiun dan Kabupaten Jember masing-masing $50 \%$.

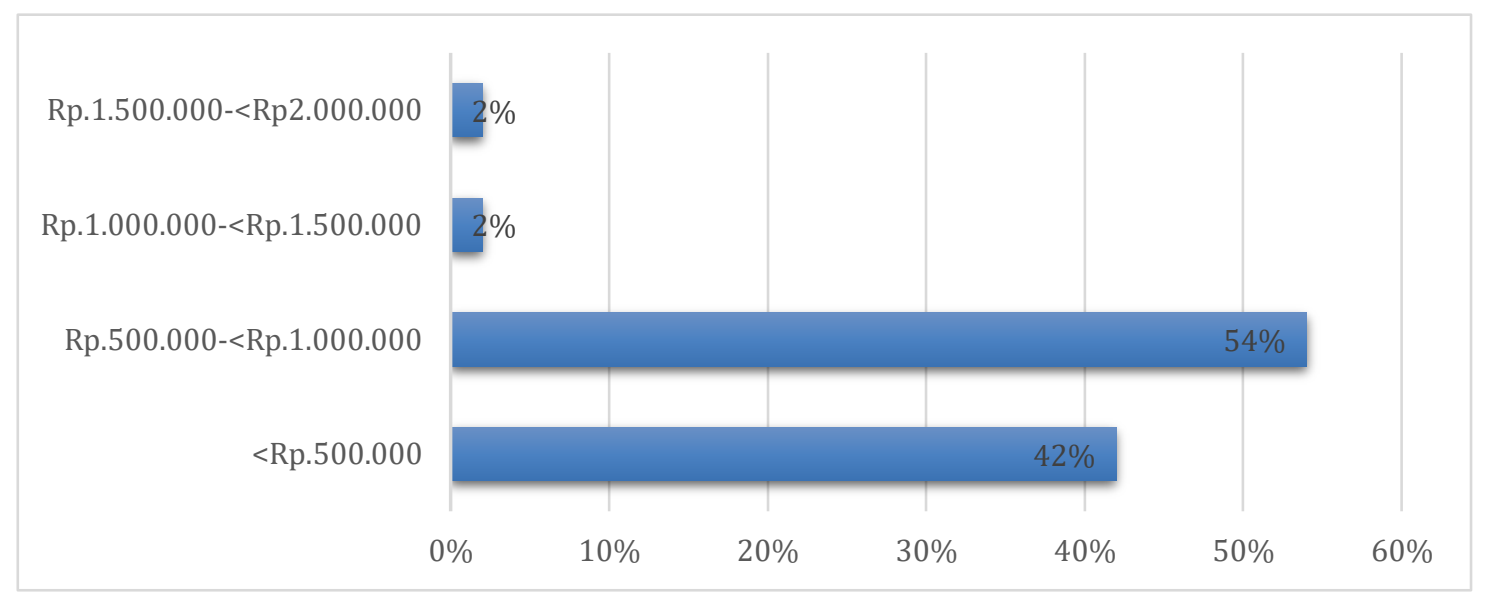

Grafik 14. Besaran Peningkatan Pendapatan

Besaran nominal peningkatan yang paling banyak yaitu Rp.500.000-<Rp.1.000.000 yaitu sebesar $54 \%$. Terbesar kedua kenaikan pendapatan yaitu <Rp. 500.000 sebanyak $42 \%$. Dari tabel di bawah bisa dilihat kenaikan pendapatan penerima program Jalin Matra PK2. Nominal kenaikan $<$ Rp.500.000 paling banyak di Kabupaten Jember sebesar 43,7 \%, terbanyak kedua di Kabupaten Malang 29,6 \%, terbanyak ketiga yaitu di Kabupaten Madiun 26,7 \%. Kenaikan Rp.500.000$<$ Rp.1.000.000 paling tinggi di Kabupaten Sumenep sebesar 38,8 \%. Kenaikan Rp.1.000.000$<$ Rp.1.500.000 hanya terdapat di Kabupaten Sumenep sebanyak 100\%. Sedangkan kenaikan Rp.1.500.000-<Rp.2.000.000 paling tinggi di Kabupaten Madiun dan Kabupaten Sumenenp masingmasing $50 \%$. 


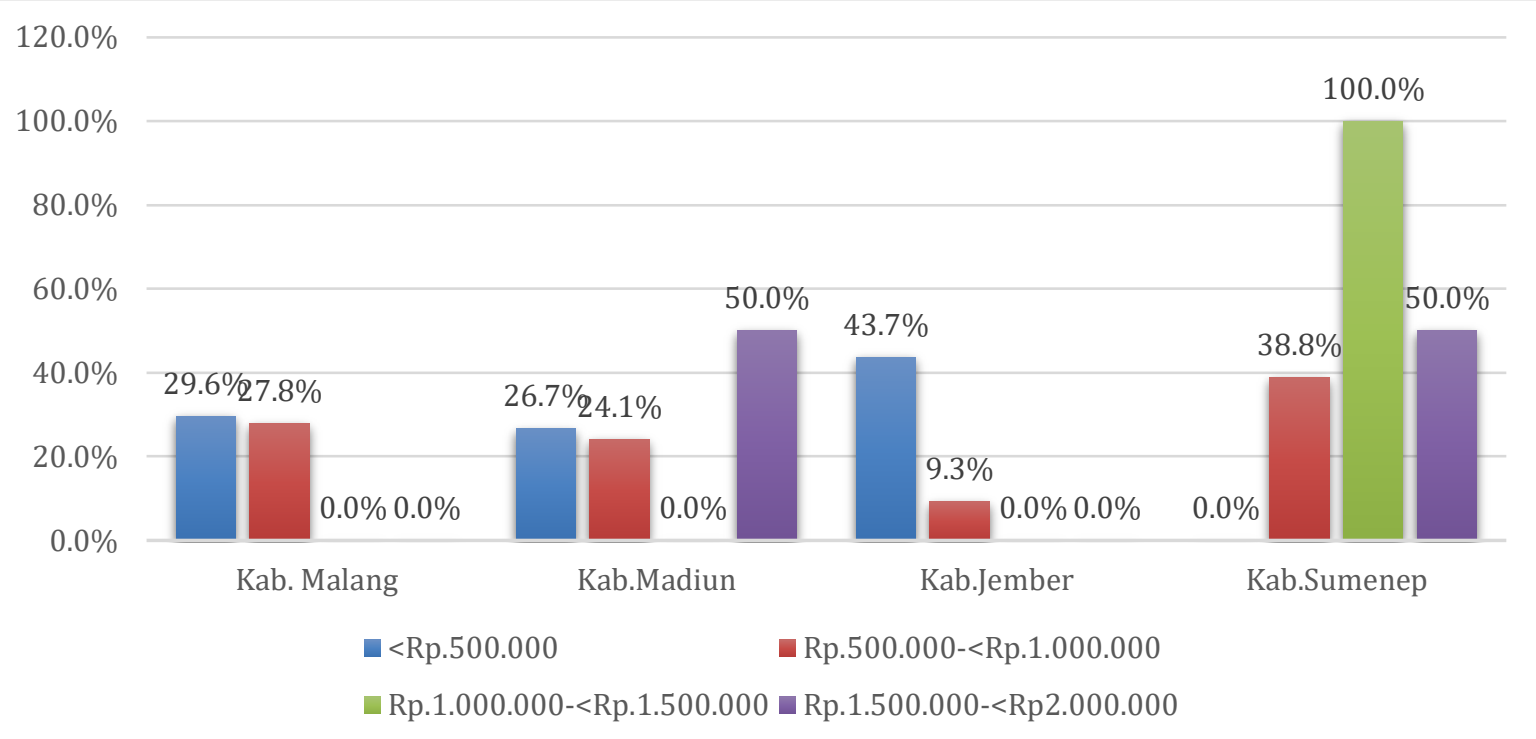

Grafik 15. Nominal Peningkatan Pendapatan

Dampak Program Jalin Matra PK2 selain pendapatan yang paling banyak dirasakan oleh responden yaitu bertambahnya barang dagangan (aset) yaitu sebesar $43 \%$, responden juga menilai dengan adanya program ini bertambah varian barang dagangan sebesar $28 \%$. Program Jalin Matra PK2 juga dinilai bisa memberikan peningkatan ketrampilan penerima program yaitu sebesar $16 \%$. Penerima program juga memperoleh penambahan alat produksi dengan program ini sebesar $10 \%$. di Kabupaten Malang dampak selain pendapatan yang paling banyak yaitu bertambahnya variasi barang dagangan 60 $\%$. Di Kabupaten Madiun dampak yang paling banyak dirasakan yaitu bertambahnya barang dagangan (aset) sebesar $76 \%$, begitu pula di Kabupaten Sumenep sebesar $68 \%$. Kabupaten Jember dampak yang paling banyak dirasakan yaitu meningkatnya ketrampilan sebesar $36 \%$.

\section{Dampak Sosial Program Jalin Matra PK2}

Dampak sosial Progam Jalin Matra PK2 yang sangat signifikan yaitu bisa mengurangi ketergantungan terhadap rentenir yaitu sebesar $51 \%$, sampak sosial kedua yaitu mempererat kerja sama warga masyarakat $26 \%$, menambah persaingan usaha $11 \%$, menciptakan pengusaha baru $9 \%$ dan lainlain $3 \%$. Di Kabupaten Malang dan Kabupaten Jember dampak sosial yang paling banyak yaitu berkurangnya ketergantungan terhadap rentenir, Kabupaten Malang $68 \%$, sedangkan Kabupaten Jember mencapai $80 \%$. Sedangkan di Kabupaten Madiun dampak sosial yang paling signifikan yaitu 
mempererat kerja sama warga masyarakat, sedangkan di Kabupaten Sumenep dampak sosial yang paling banyak yaitu menambah persaingan usaha sebesar $32 \%$.

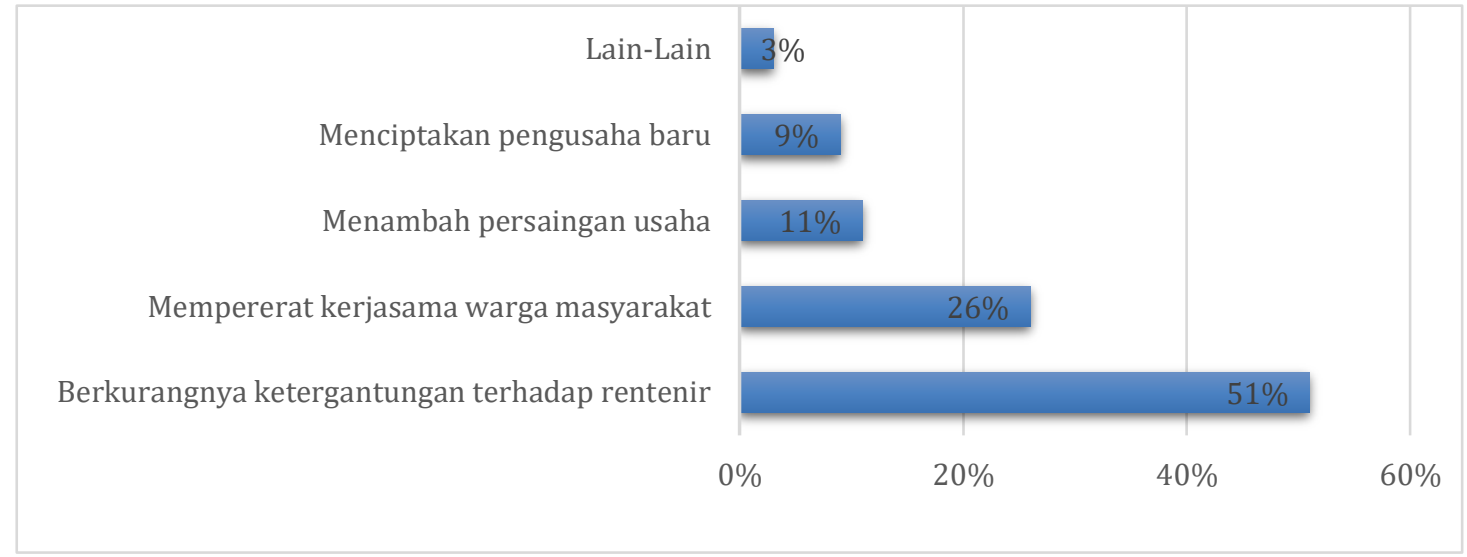

Grafik 16. Dampak Sosial Jalin Matra

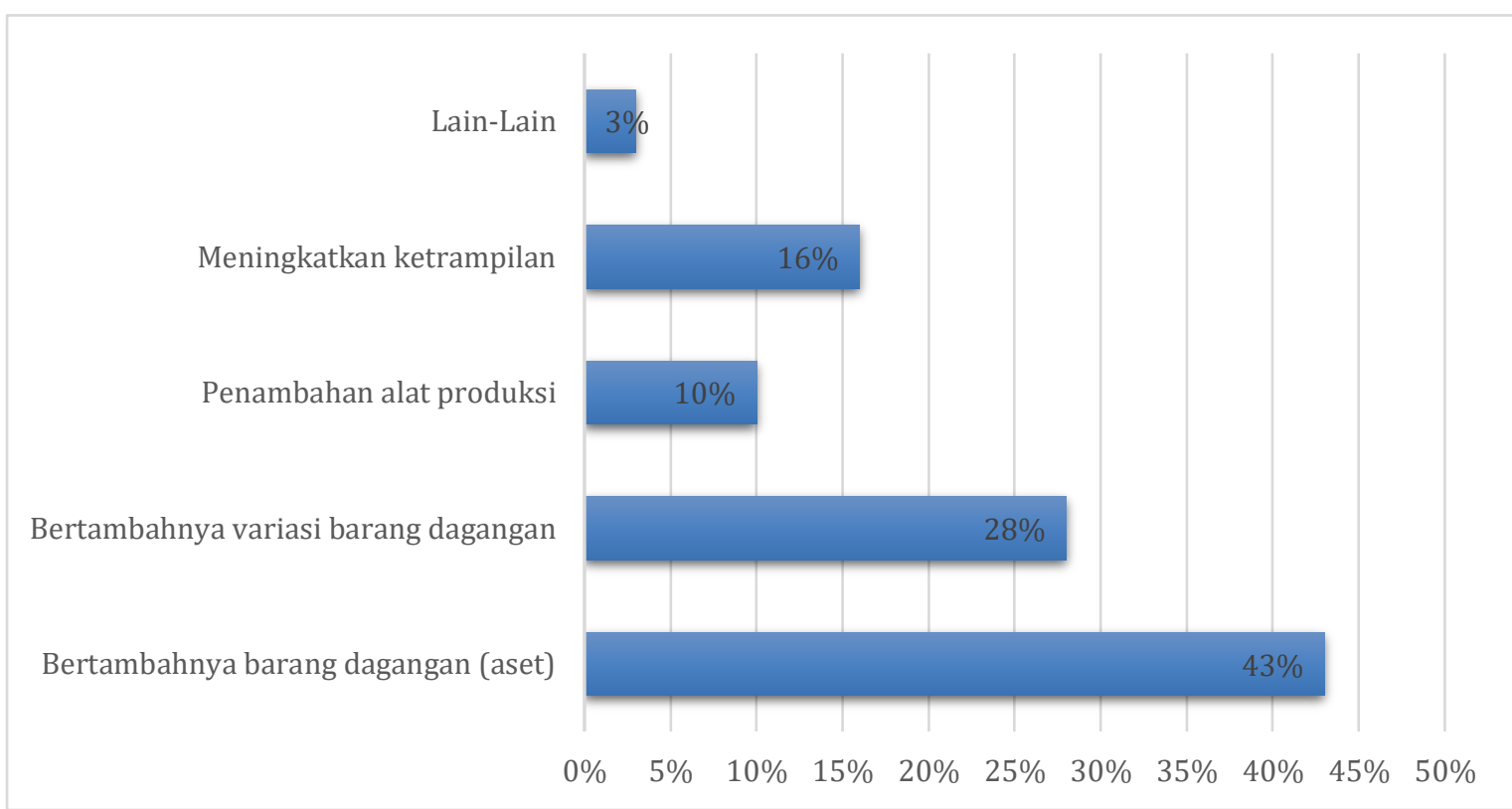

Grafik 17. Dampak Jalin Matra Selain Pendapatan

\section{SIMPULAN}

Hasil evaluasi program Penanggulangan Kerentanan kemiskinan (PK2) di lokasi penelitian berdasarkan data temuan lapangan, baik melalui pengukuran kuantitatif dan juga penggalian kualitatif menunjukkan hasil evaluasi yang memuaskan. Evaluasi Program Jalin Matra PK2 secara kuantitatif dipersepsikan oleh responden baik, dari responden yang diteliti baik pengguna dan stakeholder yang terlibat mayoritas menyatakan baik yaitu sebesar $54 \%$. Responden juga ada yang menilai program ini sangat baik sebesar $32 \%$, cukup baik $11 \%$ dan hanya $3 \%$ yang menilai program Jalin Matra PK2 kurang baik. Sedangkan data kualitatif menunjukkan, program Jalin Matra PK2 mampu menjadi pemantik tumbuh kembangnya usaha produktif di desa lokasi penelitian.

Kendala yang dapat menjadi hambatan dalam implementasi program Penanggulangan kerentanan kemiskinan (PK2) di lokasi penelitian, pertama, yang paling mengemuka secara kuantitatif 
yakni sebesar 22\% responden yang menyatakan terdapat kendala dalam klasifikasi RTS. Setelah peneliti mendalami dengan melakukan indepth interview, adanya keluhan tentang data RTS yang dijadikan rujukan sudah tidak sesuai dengan kondisi eksisting di lapangan. Kedua, kendala terbesar kedua ada pada verifikasi dan penilaian kelayakan usaha, data kuantitatif menunjukkan sebesar $12 \%$. Sementara itu, berdasarkan penggalian data kualitatif, peneliti menemukan adanya isu terkait dengan honorarium pengelola BUMDesa terutama yang terkait dengan program Jalin Matra PK2. Karena honorarium pengelola BUMDesa tidak diatur dalam buku pedoman pelaksanaan, maka tiap desa memiliki inisiatif yang berbeda, ada desa yang mengambilkan dari SHU, sehingga honorarium didapatkan ketika BUMDes sudah mendapatkan SHU. Namun ada juga honorarium dibebankan langsung pada penerima program, melalui bunga pinjaman sebesar 1,5\%, dengan hitungan $1 \%$ untuk BUMDesa dan $0,5 \%$ untuk pengelola. Tentu dengan bunga yang lebih tinggi dari Bank akan memberatkan bagi penerima program, dan ancaman kredit macet menjadi mengemuka, dampaknya dana berhenti bergulir, dan program tidak berlanjut.

Dampak implementasi program Penanggulangan kerentanan kemiskinan (PK2) terhadap peningkatan pendapatan Keluarga Rentan miskin secara umum di lokasi penelitian menunjukkan angka yang memuaskan, yakni $63 \%$ responden menyatakan pendapatannya meningkat, $23 \%$ responden menyatakan pendapatannya cukup meningkat, dan $8 \%$ yang menyatakan sangat meningkat. Hanya $6 \%$ responden yang menyatakan kurang meningkat, sedangkan dampak di luar peningkatan pendapatan yang dirasakan responden adalah Dampak Program Jalin Matra PK2 selain pendapatan yang paling banyak dirasakan oleh responden yaitu bertambahnya barang dagangan (aset) yaitu sebesar $43 \%$, responden juga menilai dengan adanya program ini bertambah varian barang dagangan sebesar $28 \%$. Program Jalin Matra PK2 juga dinilai bisa memberikan peningkatan ketrampilan penerima program yaitu sebesar $16 \%$. Penerima program juga memperoleh penambahan alat produksi dengan program ini sebesar $10 \%$.

\section{DAFTAR PUSTAKA}

Bruce SJ (1994) Social Policy, from Theory to Policy Practice, second edition. California: Brooks/Cole Publishing Company.

Dunn W (2000) Pengantar Analisis Kebijakan Publik. Yogyakarta: Gadjah Mada University Press.

Edi S (2005a) Membangun Masyarakat Memberdayakan Rakyat: Kajian Strategis Pembangunan Kesejahteraan Sosial dan Pekerjaan Sosial . Bandung: Refika Aditama.

Edi S (2005b) Analisis Kebijakan Publik: Panduan Praktis Mengkaji Masalah dan Kebijakan Sosial, Bandung: Alfabeta.

Edi S (1997) Pembangunan, Kebijakan Sosial dan Pekerjaan Sosial: Spektrum Pemikiran. Bandung: LSP Press.

Endro W (2017), Kompleksitas Kebijakan Peningkatan Kesejahteraan Sosial, Media Informasi Penelitian Kesejahteraan Sosial Vol 41 No 3, Jakarta: E-journal Kemensos.

Midgley J \& Livermore M (2009). The Handbook of Social Policy. Sage publications. 
National Association of Social Worker (1971) Encyclopedia Of Social Work, Vol II. National Association of Social Worker. Inc.

Osterle A (2002) Evaluating Equity in Social Policy: A Framework for Comparative Analysis. London: Sage Publication.

Robert M (1979) Social Policy of the American Welfare State. Harper \& Row Publisher.

Winarno B (2007) Kebijakan Publik: Teori dan Proses, Yogyakarta: Media Pressindo. 